Бојан Жикић

Одељење за етнологију и антропологију, Филозофски факултет, Универзитет у Београду bzikic@f.bg.ac.rs

\title{
Младен Стајић
}

Институт за етнологију и антропологију, Филозофски факултет, Универзитет у Београду mladen.stajic@f.bg.ac.rs

\section{Марко Пишев}

Институт за етнологију и антропологију, Филозофски факултет, Универзитет у Београду marko.pisev@f.bg.ac.rs

\section{Нова друштвена и културна нормалност и ковид-19 у Србији од фебруара до маја 2020. године}

Апстракт: Стање изазвано појавом ковида-19 можемо да посматрамо као критичан догађај: типолошки, то је догађај без преседана, који изискује и обликује нове врсте повесног деловања, до данас непознатог у датом контексту. Критични догађаји служе као снажни вредносни и емотивни оријентири у културној когнитивности сваке средине и на основу њих се врши значењско одређивање према другим догађајима. На материјалу прикупљеном првенствено у интернет верзијама електронских и штампаних медија разматрамо на који начин је кроз вести, представљене у њима, обликована стварност кроз изјаве државних управљача и лекара у Србији. Показујемо како је текао наративни преображај социокултурне стварности из времена пре избијања опште заразе ковидом- 19 у нашој земљи до времена непосредно након укидања ванредног стања проглашеног због те заразе. Претпоставка је да све што се ради и што се радило да би се изашло на крај са заразом није сврха само себи, већ има за циљ омогућавање повратка оном животу на који смо навикли пре избијања заразе. Ковидом-19 дестабилизована је наша свакодневица. Таква свакодневица јесте референцијална тачка „нормалности“. Социокултурна нормалност односи се на уобичајено и неометано одвијање свакодневних активности. Појава ковида-19 изнедрила је појам „нове нормалности“, то јест одвијања свакодневног живота који је налик нормалном, уобичајеном животу, али уз придржавање мера донетих од стране власти чији је циљ спречавање ширења заразе. У тескту се бавимо периодом који започиње непосредно пре избијања зара- 
зе ковидом-19 у нашој земљи, а окончава периодом по укидању ванредног стања, да бисмо показали како се дискурзивно производи слика друштвене стварности у којој појам „нове нормалности“ има посредничку културно когнитивну улогу експланаторног средства ситуације у којој се мора живети са заразом да би се једног дана могло вратити начину живота какав је постојао пре њега.

Кључне речи: друштвена и културна нормалност, критичан догађај, обреди прелаза, културна когнитивност, електронски/ интернет медији

\section{Увод}

У тексту „Индекс 'корона’: симболичка употреба ковида-19 у јавном говору Србије“" разматрали смо начин на који се у српском друштву и култури оперисало ковидом-19 као метонимијским, метафоричким и вредносно-значењски инверзивним средством културне комуникације (Pišev, Žikić, Stajić 2020). Као и у том случају, и овде су у средишту истраживачке пажње били чиницоци вести, то јест креатори државних и јавних политика и медицински стручњаци који су говорили у њихово име. На материјалу прикупљеном првенствено у интернет верзијама електронских и штампаних медија покушаћемо да покажемо на који начин је кроз вести представљене у њима обликована стварност кроз изјаве државних управљача и лекара, односно како је текао наративни преображај социокултурне стварности из времена пре избијања опште заразе ковидом-19 у нашој земљи до времена непосредно након укидања ванредног стања проглашеног због те заразе.

Стање изазвано појавом ковида-19 може да се означи као критични догађај терминологијом усвојеном у антропологији. То се односи на догађаје без преседана, који изискују и обликују нове врсте повесног деловања, до тада непознатог у датом контексту. Критични догађаји служе као снажни вредносни и емотивни оријентири у културној когнитивности сваке средине и на основу њих се врши значењско одређивање према другим догађајима, како онима чији је повесни след довео до њих, тако и онима на које се гледа као на њихове последице (Das 1996, 5). Истина је да се то у случају ковида-19 односи на цео свет, практично, али овде ћемо то посматрати у контексту наше земље. Време које наступа или које је наступило након појаве те болести и првих организованих државних одговора на њега широм света већ је почело да се назива „новом нормалношћу“ - у медијима, пре свега - па ћемо га и ми тако звати, тим пре што је сам назив бременит социокултурним значењем ${ }^{1}$.

1 Треба обратити пажњу на то да се израз појавио, на одређен начин, као „објашњење“ тога каква нас социокултурна стварност очекује након појаве опште заразе ковидом-19, те да је послужио као опис у прво време неименованог таквог 
Дати назив конотира друштвену и културну промену и то такву за коју се не може знати (бар не још увек) да ли је трајна. Осим тога, представља искривљену аналошку референцу на стање пре критичног догађаја, да се тако изразимо, пошто упућује на сличност у знатној мери са њом, али нипошто и истоветност. У нареченом изразу, напокон, садржана је и друштвена телеологија - или макар жеља за њеним постојањем: све што се ради, односно радило да би се изашло на крај са заразом није само себи сврха, већ има за циљ омогућавање повратка оном животу на који и на какав смо навикли. Оно што је погођено ковидом-19 у социокултурном смислу, наиме, јесте наша свакодневица - живот који се састоји од рада или учења, коришћења слободног времена, дружења и томе слично. Таква свакодневица јесте референцијална тачка „нормалности“, у ствари, онда када се говори о животу пре, за време и након стања опште заразе ковидом-19. Како дато стање није прошло, заправо, нити знамо хоће ли и како ћемо то сазнати уопште, израз „за време заразе“ односи се у контексту овог текста на ванредно стање које је у Србији било на снази од 15. марта до 07. маја. 2020. године.

Ванредно стање представља средишњицу (текућег) критичног догађаја изазваног општом заразом ковидом-19 у Србији. Оно је међаш свакодневице „пре и после короне“, како се то каже колоквијално, пошто су се управо током његовог трајања десиле све оне појаве које су избациле ту свакодневицу и наше животе из претходног, устаљеног тока, то јест онога што називамо нормалношћу. Баш та чињеница и омогућава да се о свакодневици након укидања ванредног стања у Србији говори као о „новој нормалности“, пошто омогућава тачку поредбеног дисконтинуитета. Свакодневица сама по себи није предмет овог текста, односно није то у чињеничном смислу. Као што смо већ рекли, у њему разматрамо не стварност саму по себи, већ њену слику, то јест њену наративну и дискурзивну конструкцију у вестима од стране оних који највише утичу на обликовање стварности и иначе државних и друштвених управљача, као и лекара позваних од стране тих управљача.

Обликовање стварности у вестима, а које се односе на заразу вирусом САРС-КоВ2, односи се на усмерено, политичко приказивање стања у друштву изазваног њом или под њеном претњом. Обухваћен је период од фебруара до маја 2020. године, односно време у којем је ковид-19 најпре почео да добија знатнији простор у нашој јавности, а са тим и да привлачи пажњу званичника, затим ванредно стање, те напокон период од првих неколико седмица по његовом укидању. Последњи период ограничили смо на

стања, упор. Lichfield 2020, па затим https://emergeconf.io/blog/gideon-lichfieldemerge-2020. 
време до краја месеца маја због тога што смо сматрали да мора постојати колико-толико прецизна одредница временске контекстуализације истраживања ${ }^{2}$. Било да се оно што се сада назива „нова нормалност“ устали у смислу асимптотске сличности са „животом пре короне“, било да се социокултурна свакодневица изметне у нешто битно различито од тога, или да се свакодневица у потпуности „врати“ у претходно стање - феномени на којима то све почива могли би се пратити истраживачки годинама, а наш циљ је да допринесемо разумевању наративног и дискурзивног обликовања, то јест медијског представљања преласка из „нормалности“ у „ненормалност“, па затим у „нову нормалност“.

\section{Етнографија вести}

На почетку ширења вируса из Кине, Светска здравствена организација је представила заразу као „инфодемију“. Израз „инфодемија“ употребљен је као кованица израза „информације“ и „епидемија“ и требало је да конотира то да је у питању медијско конструисање заразе - тачније, да свету поручи да не постоји толика опасност од ковида-19 као што су одмах претпоставили поједини епидемиолози (Zarocostas 2020). Дати израз упућивао је на то да су медији чиниоци обликовања знања о ковиду-19 и да прве рекације људи широм света (медицинара, политичара, тзв. обичних грађана) представљају одговор на конструкцију заразе, а не на болест у чињеничном смислу. ${ }^{3}$ У том смислу, пласирању израза „инфодемија“ следиле су препоруке $\mathrm{C}^{3} \mathrm{O}^{4}$ о томе да не треба захтевати прекид промета људи и робе са Кином, нити затварати државне границе.

${ }^{2}$ Културна мисао средине у којој живимо и о којој пишемо даје нам за право у томе, на одређени начин: време се културно контекстуално концептуализује тако да се календарске одреднице, односно календарски дефинисани почеци и завршеци узимају као оријентири у сегментирању социокултурног времена, па су тако, рецимо, одлуком нишког штаба за ванредне ситуације од 21.05.2020. године закупци градских локала ослобођени плаћања закупа за период 15.05-31.05.2020. https://www.b92.net/biz/vesti/srbija.php? yyyy $=2020 \& \mathrm{~mm}=05 \& \mathrm{dd}=20 \&$ nav id $=1686003$

${ }^{3}$ СЗО отпочела је, у сарадњи са представницима друштвених мрежа попут Фејсбука, Твитера и Тик Тока, борбу усмерену ка сузбијању дезинформација и промовисању службених информација на овим платформама. https://www.b92. net/info/vesti/index.php? yyyy $=2020 \& \mathrm{~mm}=02 \& \mathrm{dd}=26 \&$ nav_category $=12 \&$ nav id $=1659214$

${ }^{4}$ Портпарол СЗО изјавио је да би затварање граница узроковало повећање илегалног кретања људи и робе. https://www.b92.net/info/vesti/index. php?yyyy $=2020 \& \mathrm{~mm}=01 \& d d=31 \&$ nav_category $=78 \&$ nav_id $=1649075$ 
Мање од месец дана пре увођења ванредног стања у Србији, узрокованог општом заразом ковидом-19, на сличан начин је ова болест представљања и од наших чиниоца вести. Вирус који је изазива назван је дословно „најсмешнијим у историји“, тврдило се да не може да зарази децу, па чак и да га деца не могу пренети одраслим особама, да су Срби генетски отпорни на њега, да су у опасности само мушкарци, препоручивало се путовање ради наводно јефтине куповине у тадашње жариште заразе у Европи (у смислу тога колико је вирус безопасан - конкретно по жене), говорило се да су бели лук и алкохол довољно делотворни за спречавање његовог развијања у болест, да није толико значајан у поређењу са другим друштвеноекономским темама да би о њему државни управљачи водили неког нарочитог рачуна, те да је у крајњем смислу - шта год тај вирус био - Србија спремна за њега. ${ }^{5}$ Штавише, последње седмице пред увођење ванредног стања у Србији, када су већ били забележени први случајеви оболевања од ковида-19 у нашој земљи, препоручивано је да образовне установе не прекидају рад, а министар просвете и науке јавно је поручивао директорима школа које би то учиниле да ће их позвати на одговорност уколико самоиницијативно прекину одржавање наставе. ${ }^{6}$

Основне поруке које су биле послате на такав начин, и које су уоквириле такозвани званични дискурс о ковиду-19 у Србији пре проглашења ванредног стања, те самим тим обликовале доживљавање опасности од те болести у нашој средини, могу се сагледати као здравствене, управне и опште. Прве су се односиле на преношење виђења дотадашњих искуствених сазнања о ковиду-19 у свету, која су у медијима износили за то одабрани лекари; друге на преношење мишљења државних управљача о (не) важности датог феномена за друштвени и привредни живот наше земље (у којој се још није био испољио тада у пуном замаху); а треће на уверавања државних функционера о томе да је стање установа и других битних елемената друштвене структуре у нашој земљи такво да болест или неће имати значајнијих последица по функционисање свакодневног живота у њој, или да су капацитети кључних сектора државе такви да ћемо, као друштво и држава, са њом изаћи на крај на задовољавајућ начин.

${ }^{5}$ На конференцији за медије, одржаној у Председништву Србије 26. фебруара, изнето је низ шаљивих коментара са циљем да се истакне неутемељеност страха од новог вируса. http://www.nspm.rs/hronika/vucic-26.-februara-nasao-sam-sebi-dodatni-razlog-da-popijem-po-jednu-casicu-rakije-dnevno-nestorovic-najsmesniji-virusu-istoriji-covecanstva-koji-na-fejsbuku-postoji-vucic-danas-nemojte-da-lazete-nikonije-rekao-da-je-najsmesniji-virus.html?alphabet=1

${ }^{6}$ Посебно су критиковане две гимназије из Београда и Чачка које су самоиницијативно престале са радом и најавио инспекцијску истрагу по окончању кризне ситуације. https://www.b92.net/info/vesti/index.php?yyyy=2020\&mm=03\&dd=13\&nav category=12\&nav_id=1666108 
Може се рећи да је такво обликовање доживљавања ковида-19 - као својеврсне инфодемије - практично и само било нека врста инфодемије. Дата болест конструисана је дискурзивно и медијски представљана као нешто мало јача или необичнија верзија сезонског грипа, чије последице по становништво у целини не могу бити битно различите од оних које имају сезонске епидемије грипа, при чему је у тако обликованим вестима пренебрегавана чињеница, рецимо, да је школски распуст ове године био продужен за недељу дана управо због сезонске епидемије грипа - о којој иначе нису саопштавани статистички подаци (број и демографска структура заражених), нити је јавност била превише заинтересована за њих (нити је била икада у сличним ситуацијама, право буди речено). ${ }^{7}$ То је довело до парадоксалних појава у друштвеној стварности - у области спорта, на пример - у којој се у првој седмици по бележењу првих оболелих од ковида-19 у нашој земљи инсистирало на одржавању такмичења за викенд (онај на чијем крају је проглашено ванредно стање), да би који дан пре тог викенда државни врх одлучио да би их ипак требало одржати без публике. ${ }^{8}$

Карактерисање званичног дискурса у Србији до средине марта ове године као инфодемије, односно као тежње да се дискурзивно обликује оно што се представља тако да се у јавности умањи страх од болести, засновано је на томе да је у свету у то време било објављено више научних студија, спроведених махом у Кини, које су указивале на високу заразност и, да се тако изразимо - демографску недискриминативност вируса САРC2-КоВ, али и на то да болести дисајних органа, иако најчешће, нису једина њена здравствена последица (в. нпр. Kam et al. 2020; Alipio 2020; Xu et al. 2020). Поред тога, стање у појединим државама, у датом периоду више погођеним заразом него у остатку света, као и мере које су почеле да предузимају одређене државе у намери да спрече ширење заразе на њихове територије, упућивале су на потребу пажљивијег разматрања тога шта би требало радити да вирус не доспе у нашу земљу, те како спречити његово неконтролисано ширење када ту једном доспе (упор. Iacobucci 2020; Takeuchi 2020; Greene et al. 2020: Bernard-Stoecklin et al. 2020). ${ }^{9}$

${ }^{7}$ Министар здравља изјавио је 26. фебруара да је коронавирус доста слабији од обичног сезонског грипа од кога је у Србији оболело 24000 особа. https://insajder.net/sr/sajt/vazno/17045/

${ }^{8}$ Председник државе најавио је 11. марта да ће се спортска такмичења на отвореномигратипредпубликом,дабидваданакаснијепремијеркасаопштилаодлуку Владе Републике Србије о забрани присуства публике на фудбалским утакмицама. https://www.b92.net/sport/fudbal/vesti.php? yyyy=2020\&mm=03\&dd=13\&nav id $=1666075$

9 Пажњу медија посебно је привлачило стање у жаришним областима, Италији и земљама у региону, а извештаји су најчешће праћени основним информацијама 
Не можемо знати, наравно, да ли је на неким састанцима са којих јавност није извештавана расправљано у том правцу, али чињеница остаје да је представљање ковида-19 као инфодемије у званичном дискурсу у Србији довело до уобличавања одређених претпоставки о тој болести као образаца који установљавају културну мисао о њој. Слично томе, као што ce на AIDS гледало дуго времена као на „болест наркомана, курви и педеpa“ (Žikić 2006), ковид-19 је у културну когнитивност наше средине ушао као болест која напада дисајне органе старих људи, евентуално особа са озбиљним хроничним здравственим проблемима, од које не треба да се плаше млађе особе, као ни оне које су доброг здравственог стања. ${ }^{10}$ Може се претпоставити да је такав ментални образац мишљења о датој болести утицао на прилично опуштен однос који је становништво наше земље имало према њој, практично све док бројеви заражених и умрлих нису почели да постају вишецифрени. Томе у прилог говори и запамћено (да не кажемо: аутоетнографски забележено) стање у Београду два дана пре проглашења ванредног стања (а које је показивало тенденцију понављања у одређеном облику и у ванредном стању изван времена забрањеног кретања): људи шетају, рекреирају се и седе по парковима (или кафићима док се могло), без нарочитог обраћања пажње на међусобну физичку удаљеност, и без назнаке употребе заштитних средстава.

Проглашавање ванредног стања и (прве) мере које су заједно с њим ступиле на снагу заобишле су сваку причу везану за коронавирус и болест коју он изазива. Осим што је наведено да се земља „бори против невидљивог непријатеља“, дискурзивна пажња усредсређена је одмах на последице те борбе, то јест, посредно - на последице ширења заразе по свакодневни живот у нашој земљи. ${ }^{11}$ Донете мере нећемо наводити детаљно, ${ }^{12}$ већ ћемо се

о вирусном обољењу и мерама превенције. https://www.b92.net/bbc/index. php? yyyy $=2020 \& \mathrm{~mm}=03 \& \mathrm{dd}=08 \&$ nav_id $=1663840$

10 Један познати лекар изјавио је 15 . марта да се до 2003. године корона вирус сматрао изазивачем кијавице, да за већину људи није опасан и да је фаталан за старе с хроничним болестима, док су деца и здраве жене до четрдесет година старости готово имуни. https://www.espreso.rs/vesti/drustvo/525281/mi-smo-vec-nakraju-epidemije-ne-znam-sta-bi-revolucionarno-moglo-da-se-desi-doktor-nestorovicizneo-novu-prognozu

${ }^{11}$ Председник државе, приликом проглашења ванредног стања, нужност донетих мера дефинисао је речима: „Затвара се живот да би сачували живот“. https://www.b92.net/info/vesti/index.php?yyyy=2020\&mm=03\&dd=15\&nav category $=12 \&$ nav_id $=1666753$

12 Донете уредбе и мере могу се видети на линковима: https://www.b92.net/info/vesti/ index.php?yyyy $=2020 \& m m=03 \& d d=16 \&$ nav_category $=12 \&$ nav_id $=1666792 ; \quad$ https:// www.b92.net/info/vesti/index.php?yyyy $=2020 \& \mathrm{~mm}=03 \& \mathrm{dd}=16 \&$ nav_category $=11 \&$ nav id=1667094; https://www.b92.net/info/vesti/index.php?yyyy=2020\&mm=03\&dd=17\&nav 
осврнути само на дискурзивно уобличавање и телеолошко употребљавање болести у вестима које образлажу те мере. Оно што је од стране чиниоца вести наведено као њихова сврха јесте (дискурзивно и медијски пренето) усмереност читаве борбе против ширења заразе на спречавање да од ковида-19 оболе особе у најстаријој животној доби. Слично појму зрелости - који је у суштини биолошка одредница, па се мора културно производити (упор. van Gennep 1969, 65-70) - и старост јесте биолошка категорија, која у људском друштву бива одређена најчешће административно. У овом случају, као социокултурна граница старости узета је биолошка доб од 65 година, чиме се старост изједначава, практично, са економском непродуктивношћу, пошто барем у нашем друштву представља законску границу за одлазак у пензију (упор. Milosavljević 2010a,b, 2018).

Ковид-19 постао је, тако, у дискурзивном и медијском смислу пре свега болест старих људи. Издвајање, или наглашавање, тог елемента малопре описаног културно когнитивног обрасца дате болести представљено је као намераван чин. Његова сврха, па са њом и смисао целокупног низа предузетих мера, јесте друштвена, тачније међугенерецијска солидарност. За разлику од инфодемичности претходне фазе обликовања вести преношењем изјава државних званичника и одабраних лекара, за коју смо показали да је занемарила у доброј мери искуствено стање са ковидом-19 у другим социокултурним срединама, временски период у којем је проглашено ванредно стању у Србији, па надаље, одликује се таквим обликовањем вести о датој болести које не само што узима у обзир једно од њених битних својстава - већу заразност и већу смртност најстаријих људи, већ га наглашава као њено најважније својство. ${ }^{13}$

У том смислу, и мере које су предузете - где мислимо на све, односно на опште мере ограничавања кретања и спречавања физичког додира између људи, укључујући ту и забрану напуштања пребивалишта прописану за особе старије од 65 година - представљене су од стране друштвених управљача као (једини) начин заштите најстаријих грађана и грађанки од ковида-19. ${ }^{14}$ Друштвени значај тога наглашен је изјавама да ће у оним смештајним просторима који нису у власништву тих људи, а где они бора-

category=12\&nav_id=1667253; https://www.b92.net/info/vesti/index.php?yyyy=2020\&$\mathrm{mm}=03 \& \mathrm{dd}=20 \&$ nav_category $=12 \&$ nav $\mathrm{id}=1668122$

13 Председник државе чин увођења ванредног стања објаснио је као нужни начин заштите живота лица старијих од 65 година, казавши да „неће страдати наша деца, страдаће наши родитељи“.https://www.b92.net/info/vesti/index. php?yyyy $=2020 \& m m=03 \& d d=15 \&$ nav_category $=12 \&$ nav_id $=1666753$

14 Премијерка је 16. марта критиковала старије суграђане и поново је позвала пензионере да озбиљно схвате ситуацију. Описујући поштовање мера забране кретања као поражавајуће упутила је опомену: „Немојте да те- 
ве стално или привремено - у старачким домовима и болницама - рачуна о њиховој безбедности водити припадници Војске Србије, што се односило на својеврсно изузимање тих простора из спацијалних домена уобичајене друштвене приступачности (упор. Turner 1969, 96 et passim; Cohen 1985, 20 et passim) ${ }^{15}$ Држава се поставила на тај начин као скрбник друштва и тако представљена тема борбе против ковида-19 преовлађиваће у вестима до окончања ванредног стања, а у извесном смислу и непосредно након тога.

Правно донете мере проистекле из увођења ванредног стања довеле су до значајне промене свакодневног живота, како у сферама привређивања и образовања, тако и у сферама културе и слободног времена. Осим што су државни управљачи апеловали да се престане с одласком на посао и пређе на рад од куће где и коме год је то могуће, правно уведена ограничења утицала су и на потпуни прекид одређених активности: путничког градског и међумесног саобраћаја, угоститељства и туризма, кладионица и коцкарница, биоскопа и позоришта итд. С друге стране, одређене производне линије пренамењене су за произвођење оних артикала који су неопходни за борбу против заразе, попут заштитних средстава и респиратора, на пример, док су поједине привредне гране попут трговине и транспорта, рецимо, доспеле у ситуацију да се њихова активност не сме обуставити. ${ }^{16}$

Чиниоци вести су у периоду трајања ванредног стања у Србији „поделили улоге“: друштвени управљачи су говорили о ономе што смо означили као постављање државе за скрбника друштва, док су лекари говорили о болести, њеном распростирању, броју оболелих и жртвама. Лекарски дискурс био је јасно медицински ${ }^{17}$ и оријентисан сасвим супротно ономе што га је сачињавало у времену пре увођења ванредног стања. Ковид-19 третиран је у њему као изузетно озбиљно оболење о којем се не зна много, па се самим тим не може рећи прецизно ни то, када и како ћемо изаћи на крај са

рате владу да уводи полицијски час“. https:/www.b92.net/info/vesti/index. php? уууу $=2020 \& \mathrm{~mm}=03 \& \mathrm{dd}=16 \&$ nav_category $=12 \&$ nav_id $=1666797$

15 Председник државе изразио је наду 29. марта да се вирус неће појавити у геронтолошким центрима и истакао да њихову безбедност чувају припадници војске. https://www.b92.net/info/vesti/index.php?yyyy=2020\&mm=03\&dd=29\&nav category $=12 \&$ nav_id $=1670847$

16 Од избијања епидемије поједине компаније потпуно су или делимично измениле своју производњу и усмерили се на продукцију заштитних маски, одела, респиратора, дезинфекционих средстава итд. https://www.b92.net/biz/vesti/srbija. php?уууу $=2020 \& \mathrm{~mm}=04 \& \mathrm{dd}=05 \&$ nav_id $=1672676$

17 Уз поједине изузетке, када су лекари из редова чиниоца вести говорили о томе да деца треба да крену у школу, па макар да се организује „летња школа“, то јест да се настава одвија преко лета. https:/www.b92.net/info/vesti/index. php? yyyy $=2020 \& m m=04 \& d d=10 \&$ nav_category $=12 \&$ nav_id $=1674201$ 
том пошасти, понављана су упозорења која се тичу мера спречавања његовог преношења и наглашавано изнова да, осим тога што се сви морамо трудити да се сачувамо - а да ћемо то учинити најбоље поштујући мере које је донела држава - посебно опрезне треба да буду најстарије особе. ${ }^{18}$

Друштвени управљачи и лекари подједанко су истицали важност потпуне изолације људи старијих од 65 година, те су и деца и унуци позивани да их не посећују, уколико не живе са њима. ${ }^{19}$ Највећи значај у медијском посредовању стварности од стране чиниоца вести дат је превентивном деловању против ширења заразе у Србији смањивањем учесталости и потпуном обуставом физичког контакта између људи. Мера која је спровођена у циљу тога била је такозвана карантинизација, односно присиљавање на останак код куће путем полицијских часова различите дужине трајања. ${ }^{20}$ Друштвени управљачи су је бранили на основу података које су добијали о броју оболелих и умрлих од ковида-19, док су лекари истицали изнова да је једини делотворан начин борбе против вируса, који изазива ту болест, онемогућавање његовог преношења са човека на човека. То је уједно била и мера коју је било потребно нарочито оправдавати и бранити, пошто се значајан број грађана и грађанки Србије није слагао с њом, сматрајући је функционално непримереном циљу који се желео постићи њоме. ${ }^{21}$

18 Речено је да је вирус нов, да постоји могућност да уђе у осетљиви део популације и да није познато којом ће се брзином преносити. https:/www.b92. net/info/vesti/index.php? ууyу $=2020 \& \mathrm{~mm}=04 \& \mathrm{dd}=11 \&$ nav_category $=12 \&$ nav $\mathrm{id}=1674391$

19 Један од лекара из Кризног штаба 19. априла изјавио је да није препоручљиво љубљење бака и дека са унуцима и да руковање и грљење треба избегавати неко време. https://www.b92.net/info/vesti/index.php?yyyy=2020\&mm=04\&dd=19\&nav category=12\&nav_id=1676687

${ }^{20}$ Први пут забрана кретања током целог викенда уведена је у петак 10. априла и важила је до понедељка 13. априла. https://www.b92.net/info/vesti/index. php? уууу $=2020 \& m m=04 \& d d=09 \&$ nav_category $=12 \&$ nav_id $=1674034$

21 Део грађана од 26. априла почео је сваке вечери у 20:05 исказивати своје незадовољство лупањем у шерпе и лонце и прављењем буке. Непосредно пре укидања ванредног стања кренуо је протест лупањем шерпама и подизањем буке пет минута након 20 часова (у 20 часова до тада се аплаудирало здравственим радницима), за који је тешко рећи колико је био обиман - велика бука не значи и велику бројност, није се могло проценити у условима забране кретања) - као и да ли је био усмерен превасходно против таквих мера ванредног стања каква је био полицијски час, или је то био протест незадовољства управљањем кризом изазваном ковидом-19 уопште, или једноставно политички протест против власти, https://www.danas.rs/politika/u-mnogim-delovima-buka-protiv-diktature-glasnija-od-aplauza/ 
Државна скрб над друштвом појављивала се ту - тачније у изјавама државних функционера и функционерки на дату тему - као једини могући одговор на ковид-19 у Србији, међутим, пошто се у њима јасно повлачила граница између одговорног понашања државе, то јест њених установа и функционера, и неодговорног понашања грађана, где су понекад коришћене формулације ,део грађана“ и „,неодговорни грађани. ${ }^{22}$ То је било уочљиво посебно у случајевима „продирања“ вируса САРС-КоВ2 у државне установе, када су чиниоци вести из редова државних управљача упорно и изнова понављали да се припадници МУПа, Војске, различитих министарства итд. нису заразили на послу, већ изван њега. ${ }^{23}$ Тако нешто дошло је до изражаја посебно онда када је букнула зараза ковидом-19 у геронтолошком центру у Нишу, када су различити функционери и функционерке давали различите изјаве о томе због чега је до заразе дошло, а којима је заједничко било то, заправо, да на одређени начин умањују или чак одричу кривицу формацијски правно одговорног лица (које је по моделу присутном код нас невезано за режим и даље политички постављено од стране власти на ту функцију а не изабрано у колективу) и пребацују је на грађанство. ${ }^{24}$ Чиниоци вести из редова лекара у истом периоду такође су оправдавали строгост карантинизације тиме што је то најсигурнији начин да се спрече физички додири између људи, заговарајући с времена на време и такозвану потпуну, или двадесетчетворочасовну забрану напуштања стамбених простора у периоду и до две седмице. ${ }^{25}$

22 Заменик градоначелника Београда изјавио је да део грађана не поштује никакве препоруке и угрожава друге, што може приморати власти да уведу ригорозније мере. https://www.beograd.rs/cir/beoinfo/1772167-vesic-sportske-dvorane--privremene-bolnice-apelujem-na-gradjane-da-maksimalno-postuju-mere-vlade/

23 У случају државног секретара Министарства заштите животне средине Бранислава Блажића, који је касније преминуо од последица заражавања корона вирусом, медији су приликом информисања јавности да је он први припадник владе тестиран позитивно, по правилу истицали чињеницу да је реч о особи која долази из Кикинде, граду који је етикетиран као једно од жаришта епидемије у Србији. https://www.b92.net/info/vesti/index.php?уууу $=2020 \& \mathrm{~mm}=03 \& \mathrm{dd}=24 \&$ nav category=12\&nav_id $=1669456$

${ }^{24}$ Министар за рад, запошљавање, социјална и борачка питања изјавио је да је корона вирус у Геронтолошки центар у Нишу највероватније ушао када је у хотелу са којим центар дели двориште одржана изложба паса, упркос изолацији корисника центра. https:/www.b92.net/info/vesti/index.php?уyyy=2020\&mm=04\&dd=16\&nav category=12\&nav_id=1675871

25 Један од лекара из Кризног штаба објаснио је одлуку двадесетчетворо часовне забране кретања као крајњу меру која се уводи пред крај епидемије како би имала ефекта. https:/www.b92.net/info/vesti/index.php?уууy=2020\&mm=04\&dd=02\&nav category $=12 \&$ nav_id $=1671853$ 
Без обзира на извесни отпор таквим мерама од стране такозваних обичних људи, већина их је усвојила не као принуду, већ као начин заштите од могућег обољевања од ковида-19 и придржавала их се на зато што мора, већ зато што треба. Насумичне етнографске забелешке и опажања, понајпре из микросоцијалних окружења аутора̂ овог текста, али и добијене као посредна обавештења путем телефона, електронске поште или друштвених мрежа, упућују на то да се представа о стварности као о ономе што је дефинисано свакодненвом рутином (школа, посао, култура, слободно време итд.) изокренула у току ванредног стања, а поготово од његове друге седмице, у такво њено доживљавање које је било у потпуности одређено не само ванредним мерама самима по себи, већ и културно уобличеном мисли о томе да смо се, као друштво и цивилизација уопште, сусрели са проблемом за који (барем тренутно) немамо решење, те да је најбоље клонити се свега онога што у том смислу може да нас угрози. Ковид-19 „прихваћен“ је тако прећутно као основна детерминанта друштвеног и индивидуалних живота, средиште друштвеног организовања и свакодневних активности појединаца.

Битна тема у медијском промовисању државе као скрбника друштва током трајања ванредног стања била је привреда. На томе су од стране чиниоца вести инсистирали државни управљачи, разуме се, али ће се ње дотаћи и лекари у време непосредно пред укидање ванредног стања у Србији и након тога. ${ }^{26}$ Производни и сектор услуга највише су (били) погођени изменама у друштвеној свакодневици узрокованих појавом ковида-19 у Србији и шире. Нормативно ограничење кретања становништва, као и затварање граница, а поред тога и забране извоза одређених артикала, пре свега медицинских и прехрамбених, које су донеле владе многих појединачних земаља и Европске уније у целини, довели су до опадања или заустављања пословних активности у оним привредним областима којима се иначе пуне државни буџети. ${ }^{27}$ Влада Републике Србије инсистирала је од почетка ванредног стања на томе да ће пружити економску помоћ свим привредним субјектима - уколико послодавци не буду от-

26 Лекари, који су део кризног штаба, присуствовали су седници владе 28. априла на којој су донете одлуке о попуштању мера забране рада појединих привредних сектора. Један од њих најавио је поновни почетак рада градског и међуградског превоза, кафића, ресторана и тржних центара, као и вртића и продуженог боравка у школама „из потребе да привреда крене“. https://www.b92. net/biz/vesti/srbija.php?уyуy $=2020 \& m m=04 \& d d=28 \&$ nav_id $=1679103$

27 У првом кварталу 2020. године извоз Србије мањи је за 5\%, а дефицит је повећан за 7.5\%, у односу на исти период прошле године. https:/www.b92.net/biz/ vesti/srbija.php?yyyy $=2020 \& \mathrm{~mm}=05 \& \mathrm{dd}=29 \&$ nav_id $=1689185$ 
пуштали раднике - те је донела и почела да спроводи одговарајуће мере помоћи. ${ }^{28}$

У вестима је дата акција помоћи привреде српске владе такође представљана телеолошки. Имајући у виду то да су од почетка избијања опште заразе ковидом-19 у Европи кренуле процене светских финансијских стручњака о томе колики ће бити општи привредни губици, односно колико ће износити пад БДП-а које државе, државно помагање привреди у Србији је, осим социјалне, добило и такмичарску конотацију - да се тако изразимо - у изјавама званичника. Целокупна привредна ситуација у земљи процењивана је као боља од многих других европских земаља и изјављивано је како ће Србија имати један од најмањих процентуалних падова БДП-а, те да ће самим тим бити у врху европске економије у наредној, 2021. години, тачније онда када се претпоставља(ло) да ће друштвене околности какве су се десиле избијањем опште заразе ковидом-19 остати за нама. ${ }^{29}$ Постепено поновно покретање целокупне привреде - укључујући и оне делатности које су недвосмислено оцењиване као потенцијално најопасније за ширење заразе - постала је све чешћа тема у изјавама државних управљача из редова чиниоца вести како се приближавало укидање ванредног стања ${ }^{30}$.

Након неколико седмица упорног објашњавања из врха власти и од стране за то задужених лекара да је једини начин за избегавање великог и наглог пораста броја заражених особа строга изолација, ванредно стање у Србији укинуто је нагло. ${ }^{31}$ Статистика заразе није показивала битна одступања у периоду непосредно пре и непосредно након укидања ванредног

${ }_{28}$ Министар финансија изјавио је да ће пакет помоћи привреди износити 5.1 милијарду евра и да ће укључивати одлагање плаћања пореза на зараде, доприносе и добит на три месеца, а председник државе најавио је помоћ малим и средњим предузећима која нису отпустила више од $10 \%$ радника током епидемије кроз исплату три минималне зараде.

https://www.bbc.com/serbian/lat/srbija-52107193?xtor=AL-73-\%5Bpartner\%5D\%5Bb92.net\%5D-\%5Blink\%5D-\%5Bserbian\%5D-\%5Bbizdev\%5D-\%5Bisapi\%5D

${ }^{29}$ Гувернерка Народне банке Србије изјавила је: „Оцена ММФ-а је да ће Србија имати једну од најбољих стопа раста БДП-а у 2020. години, односно да ћемо имати најмањи пад од свих земаља у Европи. То је, у овим незапамћеним условима, добра околност.“" https://www.b92.net/biz/vesti/srbija. php?уууу $=2020 \& \mathrm{~mm}=04 \& d \mathrm{~d}=16 \&$ nav_id $=1675845$

30 Говоримо о времену када још нисмо знали да ће и када ће оно бити укинуто. Председник државе најавио је 18. априла отварање бројних трговачких и услужних радњи до краја месеца и отпочињање рада фабрика почетком маја.

31 Скупштина Републике Србије изгласала је 06. маја укидање ванредног стања, иако је тог дана регистровано 114 нових случајева инфекције. https:/www. 
стања, па ипак, и поред првих наговештаја да укидање не значи и одустајање од већине уведених мера борбе против ковида, врло брзо су се вести окренуле потреби за нормализацијом живота. ${ }^{32}$ Лекари из Кризног штаба такође су истицали како је време да се привреда поново покрене и да се треба враћати нормалном начину живота, односно свакодневици на коју смо навикли пре избијања заразе - али уз поштовање физичког дистанцирања и ношење заштитне опреме, пружајући на тај начин подршку своје струке за политички донете одлуке од стране државних управљача које су се косиле са њиховим претходним ставовима и препорука везаним за борбу против ковида-19. ${ }^{33}$

Државни управљачи, са своје стране, образложили су укидање ванредног стања медицинским разлозима, односно повољним статистичким развојем епидемиолошке ситуације у земљи. ${ }^{34}$ По њима, престала је потреба за ванредним мерама у целини - тачније, барем за онима које онемогућавају циркулисање људи - а остала само за мерама такозване личне заштите, то јест придржавања правила просторног размака између људи и ношења маски (и рукавица) у затвореном простору. ${ }^{35}$ Првобитно најављено

b92.net/info/vesti/index.php?yyyy $=2020 \& \mathrm{~mm}=05 \& \mathrm{dd}=06 \&$ nav_category $=11 \&$ nav $\mathrm{id}=1681303$

32 Након укидања ванредног стања јавни превоз поново је постао доступан свим грађанима, отворили су се тржни центри, дозвољени су јавни скупови до 50 људи и најављено је поновно отварање факултета, обнављање авио-саобраћаја и настављање спорских такмичења. https://www.b92.net/biz/vesti/srbija. php?уууу $=2020 \& \mathrm{~mm}=05 \& \mathrm{dd}=08 \&$ nav_id $=1681981$

33 Један од лекара из Кризног штаба исказао је уверење да је државни приступ епидемији „био одличан, али да сада све треба пустити“, уз тврдње да ће до краја маја епидемија бити завршена и да се вирус неће враћати, да ће сигурно бити одржани фестивали Егзит и Гуча и да је сада право време да се људи заразе и стекну имунитет. Истакао је и значај менталног повратка у нормалу кроз ублажавање мера социјалног дистанцирања: “видим да су људи почели да се рукују, што је лепо и да се грле, дочекали су тај моменат”. https://www.b92.net/info/vesti/index. php? уууу $=2020 \& \mathrm{~mm}=05 \& \mathrm{dd}=08 \&$ nav_category $=12 \&$ nav_id $=1682143$

34 Неколико дана пре укидања ванредног стања председник државе обзнанио је да је забележена најмања дневна процентуална зараженост до тог тренутка, што је окарактерисао као заслугу мера које су предузимане, а на које се људи љуте. Закључио је да су бројеви по градовима добри: „Ниш се опоравио драматично и Београд је бољи него јуче. Нови Сад има фантастичне резултате већ десет дана. У крагујевцу су углавном добри...“. https://www.b92.net/info/vesti/index. php? yyyy $=2020 \& \mathrm{~mm}=05 \& \mathrm{dd}=01 \&$ nav_category $=12 \&$ nav_id $=1679933$

35 Премијерка је 07. маја изјавила да, „све мере превенције и опреза остају на снази, а сада је наважнија лична одговорност“". https://www.b92.net/info/vesti/index. php? yyyy $=2020 \& \mathrm{~mm}=05 \& \mathrm{dd}=07 \&$ nav_category $=12 \&$ nav_id $=1681812$ 
постепено укидање ванредних мера убрзано је изменом одлуке о поновном успостављању градског превоза у Београду и томе да ће он бити доступан свима, а недуго након тога имали смо и политички „перформанс“ испред Скупштине ${ }^{36}$, на којем се „спонтано“ (по речима представника власти и њима блиских медија) окупило неколико хиљада људи. ${ }^{37}$ Истичући епидемиолошку заснованост својих одлука, државни управљачи су их дискурзивно додатно ојачавали позивањем на правне норме - највише на оне које су се тицале неопходности одржавања избора „у законском року“ и забрани дискриминације грађанства по било ком основу ${ }^{38}$.

С укидањем ванредног стања и објашњењима тога - како од стране управљача, тако и од стране лекара - да је не само потребно већ и неопходно да се живот врати „у нормалу“, у вестима се појавио заједнички став Кризног штаба и представника власти о томе да одговорност за заштиту од инфекције корона вирусом сада лежи искључиво на појединцима. ${ }^{39}$ Наглашавањем личне одговорности као кључне за даљи ток заразе ковидом-19 у нашој земљи, држава је лишена „скрбништва“ над друштвом дискурзивно, остајући у својству усмеривача његове будућности: чиниоци вести говорили су о конкретним мерама помоћи привреди и оживљавању економије уопште, потом о отварању државних граница и омогућавању колико је год могуће више несметаног кретања људи унутар и преко њих, затим о формалним условима које ће бити неопходно испунити да би преласци границе у оба смера били могући, уз то о инфраструктурним пројектима на којима се ради и који ће бити покренути у земљи, те напокон о предстојећим изборима. ${ }^{40}$

36 Поједини политичари из редова владајуће и неких опозиционих странки сукобили су се вербално и помало физички, а затим се надметали - такође мало - у томе ко ће бити већи уметник у гладовању, да се послужимо Кафкиним речима, пошто дату представу може одговарајуће описати само мајстор апсурда попут њега.

37 Испред Скупштине окупило се око 6000 људи, а посланик владајуће странке и учесник штрајка глађу захвалио је „спонтано окупљенима“. http://rs.n1 info.com/ Vesti/a598389/Okupljanje-ispred-Skupstine-Srbije.html

38 Председница парламента изјавила је: „Не можемо бесконачно да отежемо с одржавањем избора, у складу с изборним законима и уставом - биће одржани.“ https://www.b92.net/info/vesti/index.php?уууу $=2020 \& \mathrm{~mm}=04 \& \mathrm{dd}=25 \&$ nav category=11\&nav_id=1678192 Друго се односило на коришћење градског превоза у Београду, односно на првобитно представљена ограничења у томе. https:/www. b92.net/biz/vesti/srbija.php?yyyy $=2020 \& m m=05 \& d d=07 \&$ nav_id $=1681752$

39 Један од лекара из Кризног штаба изјавио је 07. маја да „мере остају, али то jе за личну одговорност“. https://www.b92.net/info/vesti/index.php?yyyy=2020\&mm=05\&dd=07\&nav_category $=12 \&$ nav_id $=1681839$

40 Након састанка са представницима најугроженијих сектора привреде, министар финансија истакао је да је држава спремна да помогне како би се што 
Посматрањем (без учествовања) утврдили смо да се живот у Београду заиста вратио у стање сличном ономе пре избијања заразе ковидом-19. Угоститељски и објекти за физичку рекреацију користе се углавном у сличној мери као и раније, а то важи и за градски превоз, одласке у куповину, на посао, шетње итд. Мере личне заштите примењују се минимално, рекли бисмо, а то је опажено и од стране лекара који се појављују у медијима као презентери званичног дискурса о стању изазваном ковидом-19.41 У вестима у којима се то може чути, користи се изрази „опустили смо се“ за однос грађанства према препорученим ${ }^{42}$ мерама индивидуалне заштите ${ }^{43}$ и то можемо потврдити и на основу насумичне етнографске опсервације и истих таквих разговора са људима на дату тему. С друге стране, приметно je, међутим, да - осим у такозваним саобраћајним шпицевима - учесталост коришћења јавног превоза није толико висока као у време пре проглашавања ванредног стања, а да се то може рећи и за посећивање објеката за физичку рекреацију, а поготово за свакодненву социјализацију, односно за дружење.

Слично није исто, и кратки опис ситуације пре и после ванредног стања, односно онога што је сматано врхунцем епидемије у нашој земљи у датом тренутку, упућује да о „повратку нормалном начину живота“ након окончања ванредног стања може да се говори као о некаквој „новој нормалности“ у односу на свакодневну организацију живота пре тога. И поред тога што се иде ка потпуном функционисању друштва у свим његовим сегментима, приметно је да код људи - говоримо уопштено, али сматрамо да се односи на преовлађујући број - постоји извесна уздржаност у оства-

пре покренула привредна активност и сачувала радна места. https://www.b92. net/biz/vesti/svet.php?yyyy $=2020 \& m m=05 \& d d=11 \&$ nav_id $=1682910$. Најављено je отварање граница за 01. јун, а негативан тест одређен је као услов за улазак у земљу. https://www.b92.net/info/vesti/index.php?yyyy=2020\&mm=05\&dd=12\&nav category $=12 \&$ nav_id $=1683230$

41 Један од лекара из Кризног штаба изјавио је да „показујемо да не умемо да поштујемо мере и да би требало да нам буде обавезно ношење маски и друге мере." https://www.b92.net/info/vesti/index.php?yyyy=2020\&mm=05\&dd=12\&nav category=12\&nav_id=1683086

42 Наши чиниоци вести, а поготово државни управљачи међу њима, као да заборављају да „препоручено“ и „обавезно“ нису синоними, те да израз „апел“ значи „позив““, у ствари, одакле је тешко очекивати да се већина људи придржава као обавезног нечега што није представљено на такав начин.

43 Један од лекара из Кризног штаба оценио је 10.5.2020. да су се грађани превише опустили и да је епидемиолошка ситуација и даље несигурна. https://www. b92.net/info/vesti/index.php? уууу $=2020 \& \mathrm{~mm}=05 \& \mathrm{dd}=10 \&$ nav_category $=12 \&$ nav $\mathrm{id}=1682681$ 
ривању физичких контаката са другим особама. У предузећима, трговинама, угоститељским објектима и томе слично углавном се примењују мере индивидуалне заштите запослених у њима, а одређен број људи и даље сматра да не треба да излази изван својих домова без неког практичног циља, какав је набавка неопходних потрепштина или одлазак на посао.

\section{Нормално и ненормално}

Како је то већ речено раније у тексту, када се каже да је ковид-19 изазвао значајне промене у друштвеном животу, мисли се на разарајуће дејство по свакодневицу. Рутина целог друштва заснована је на рутини појединаца и установа. Рутина се састоји од оних активности које се изнова понављају - дословно свакодневно, или посматрано у другим временским одсечцима, седмично, месечно, годишње. На пример: сваког радног дана иде се у школу или на посао, сваке седмице мења се биоскопски репертоар, месечно се врши обрачун пореза на додатну вредност, спортска такмичења одржавају се на годишњем нивоу и томе слично. Устаљено функционисање свега тога - и мноштва других активности, наравно - склони смо да посматрамо као целокупност појединачног и друштвеног живота, као рутину, свакодневицу или нормалност. Нормално у друштвеном и културном смислу, дакле, није само оно што се сматра позитивно нормираним и санкционисаним, у рецимо правном и економском смислу, и не односи се искључиво на преовлађујуће културне вредности и идеје, нити на индивидуално понашање у складу с њима (Žikić 2011). Социокултурна нормалност односи се на све то, али схваћено у кључу уобичајеног и неометаног одвијања свакодневног живота, односно активности (Allen 2008).

$\mathrm{У}$ антропологији је одавно присутно сазнање о томе да се друштвени живот одвија у фазама рутине и ритуала, односно свакодневног и обредног или празничног организовања активности. Дате фазе смењују се у ономе што се назива годишњи обредни циклус и на тај начин омогућавају културно концептуализовање протока времена (в. нпр. Gell 1992, 295, 297 et passim). Усудили бисмо се да приметимо да терминологија, која је некада била експланаторна, не помаже онда када се културно поимање времена посматра тако да обухвати оно што је у њој било означено као фазе свакодневице и обреда или празника: у савременим друштвима рутином, односно свакодневицом можемо означити целокупно устаљено и ничим ометано функционисање друштва из два основна разлога. Најпре, обредност која је на делу у њима (говоримо о оној на нивоу целог друштва, не у његовим појединачним сегментима) није више верског карактера, пошто 
су та друштва секуларна: не постоји обредно мишљење и понашање које je, онда када у концептуализацији времена наступају ритуалне фазе, битно разликује од онога које би било означено као рутинско. Државни или међународни празници одржавају се без церемонија које укључују све припаднике заједнице - као што је то био случај у оним друштвима у којима су раније етнологија и антропологија проучавале феномене који се тичу обредности, свакодневице и поимања времена.

Полагање венаца на гроб Незнаног јунака или оснивача државе, посећивање места са одређеним повесним значајем (попришта битака, страдања итд.), подсећање на датуме када су изборена нека права или почела борба за њих (радничка, родна, национална, мањинска итд.) и друге сличне церемоније не само што су пре свега протоколарног типа ${ }^{44}$, већ за њих не мари највећи број грађана и грађанки државе - који свеједно радо користе слободне дане предвиђене законом - а који представљају оно што је у класичној антропологији, да се тако изразимо, називано ритуалном фазом друштвеног живота, насупрот радној свакодневици (в. нпр. Howe 1981; Leach 1982, 202; Kovačević 2001a, 182-185; Kovačević 2001b, 96-99). Други разлог произлази одатле: државни званичници појављују се као јасни, и у највећем броју случајева једини титулари фазе празника. Они су ти који обављају протоколарне, односно церемонијалне радње које отелотворују идеју државног празника у стварности. На тај начин они су и ти који воде рачуна о подсећању на садржину или смисао празника, а таква њихова церемонијална улога произлази из њиховог друштвеног положаја: они су отелотворење метонимијског представљања државе.

Схваћена као целокупност уобичајених активности, друштвена рутина, дакле, обухвата фазе рада и фазе празновања - да их тако назовемо; и када у овом тексту говоримо о друштвеној свакодневици, мислимо на континуитет унапред уређене и предвидљиве динамике смењивања речених фаза. Већ на први поглед бива јасно шта је остало од свакодневице у „времену короне“ - стварност у потпуности обликована акцијама, односно мерама државних званичника, који су путем медија настојали да на масовном нивоу креирају доживљај стварног, будући да се медицинско, економско, правно или стање личних слобода у земљи није могло установити ни на један начин сем на основу њихових изјава. Те изјаве су биле мање или више различито оријентисане у односу на оно што је одређујући чинилац стања у земљи у временском периоду о којем пишемо - зараза ковидом-19 - и у односу на који и формулишемо оно што у тексту називамо временом „нормалности“, „ненормалности“ и „нове нормалности“.

44 У питању је оно што се у друштвеним и хуманистичким наукама назива световним, односно секуларним ритуалима, в. Mur i Majerhof 1984. 
Прва ознака односи се на временски период који се окончао увођењем ванредног стања у Србији и на стање друштвене свакодневице у њему; друга ознака односи се на ситуацију током ванредног стања, а трећа на временски период и стање друштвене свакодневице по укидању ванредног стања. Значењски однос нормално-ненормално-(скоро па) нормално који се успоставља као уопштени опис - али и доживљавање - целокупног друштвеног живота у Србији (а он ту укључује и животе појединаца, не треба то сметати с ума), у временском периоду на који се осврћемо у овом раду, може да послужи као парадигматска основа за разматрање осталих ознака које се односом према ковиду-19 појављују као својства наратива и дискурса чиниоца вести у појединачним оријентисаним временским периодима на које реферишемо датим ознакама.

Наречена парадигматска основа представља три засебне парадигме, у ствари, које одговарају културном значењу до којег се долази када се анализирају различите комуникацијске категорије укључене у њих, али која истовремено представља значењску целину сама по себи - о чему ће бити више речи даље у тексту. Комуникацијске категорије, са своје стране, представљају оне теме које су највише присутне у изјавама чиниоца вести у сваком појединачном временском периоду, и којима се придаје нарочит значај у културној комуникацији која се одвија на релацији званичници-јавност, а посредством медијски презентованих вести. Те категорије су: статус заразе, снага болести, опасност заразе и болести по појединце, стање економије, управљање кризом изазваном заразом и државом уопште, лична права и обавезе грађанства.

У суштини, оно што се мења у зависности од контекста појединачног временског периода „нормалности“, „ненормалности“ и „нове нормалности“ јесте вредносни и нормативни однос чиниоца вести - а пре свега државних управљача - према концептуалном садржају датих категорија. Треба рећи још, при том, да нису све те категорије подједнако биле присутне у вестима у сваком од временских периода којима се бавимо овде. Последња од њих, рецимо, појављује се тек у периоду „ненормалности“, док су, с друге стране, стање у економији и управљање државом у медијима стално присутне теме, било да о њима говоре они који су нам у фокусу текста, државни званичници, било да су предмет ма чијег другог разматрања. Остале теме форматиране су као предмет културне комуникације на нивоу целог друштва у потпуности, на основу избијања опште заразе ковидом-19 у свету и доласком те болести у нашу земљу, и за њих се може рећи да у садржинском смислу представљају детерминанту друштвеног стања описаног као „нормалност“, „ненормалност“ и „нова нормалност“. 
Треба обратити пажњу на то да се дискурзивно конструисање парадигматских категорија на основу раније наведених тематских наратива односи заправо на „ненормалност“ и „нову нормалност“; парадигматска категорија „нормалност“ ьихова је референтна позиција, у суштини. Онда када се говори о „нормалности“, реферише се на уобичајено стање социокултурне свакодневице, на начин живота на који смо навикнути. У том периоду нема суштинске значењске везе између пошасти и економије, или управљања државом и стања законом загарантованих грађанских права. Стање свега тога подразумева се као уобичајено, то јест нормално у истим таквим животним околностима.

Онда када зараза продире преко државних граница, према њој започиње дискурзивни однос као према туђину који продире у друштвено ткиво (Csordas 1990, 2012; Singer 2004). Очигледно парање тог ткива изазива функционалну реакцију државне управе, а доношење мера које треба да спрече проширивање малициозног деловања заразе на одређени начин доприноси промени свакодневног живота у свим његовим сегментима, слично као и зараза. Неминовност таквог нечега тематска је суштина наратива који су усмерени ка објашњавању промене начина управљања државом у смислу најбољег могућег руковођења кризом, где дискурзивно описивање здравствене опасности представља исходиште, а нужност привремене промене у начину привређивања готово свих привредних субјеката, као и начину живота појединаца представљају исходе целокупне наративне акције.

Временски период након укидања ванредног стања, са своје стране, аналоган је, у погледу медијски посредованог конструисања стварности, периоду који је претходио увођењу ванредних мера. Смисао дискурзивног конструисања стварности огледа се у грађењу наративног контраста у односу на пресек стања током принудне карантинизације становништва, те у успостављању референцијалног односа према времену пре званичног избијања заразе. Због тога, неке од кључних тема пласирају државни управљачи у вестима, пре свега, тако да покажу истоветност стања у Србији „пре и после короне“445 (попут грађанских права), неке друге да укажу на унапређеност у одређеним секторима (економија) у односу на време пре заразе, а оне које се односе на саму заразу, опет, тако да подсете на то да се са њом нисмо изборили још увек, иако се може сматрати да је суспрегнута. ${ }^{46}$

45 Како смо раније у тексту напоменули, колоквијална синтагма „после короне“ односи се на период након укидања ванредног стања у Србији.

46 А што омогућава да се друштвени живот васпостави у сличном, али опет у извесној мери измењеном облику у односу на време пре појаве ковида-19 у Србији. 
Табела 1: тематска конструкција парадигми „нормалност“, „ненормалност“ и „нова нормалност“

\begin{tabular}{|c|c|c|c|}
\hline теме & „нормалност ${ }^{66}$ & „ненормалност 6 & ,нова нормалност 6 \\
\hline статус заразе & непостојећu & висок & сманьен \\
\hline снага болести & никаква & изузетна & смањена \\
\hline $\begin{array}{l}\text { опасност заразе } \\
\text { и болести по } \\
\text { појединце }\end{array}$ & мала & веома велика & све мана и маньа \\
\hline стање економије & $\begin{array}{l}\text { уобичајено: } \\
\text { добро, може и } \\
\text { боље }\end{array}$ & $\begin{array}{l}\text { ванредно: није ломе } \\
\text { у компаративној } \\
\text { перспективи, могло је } \\
\text { горе, а биће боље }\end{array}$ & $\begin{array}{l}\text { у опоравку: биће боље } \\
\text { и у компаративној } \\
\text { перпсективи и иначе }\end{array}$ \\
\hline $\begin{array}{l}\text { управљање кризом } \\
\text { изазваном заразом и } \\
\text { државом уопште }\end{array}$ & $\begin{array}{l}\text { нема потреба за } \\
\text { тим }\end{array}$ & $\begin{array}{l}\text { основна државна } \\
\text { и друштвена } \\
\text { активност }\end{array}$ & надзирање ситуаиије \\
\hline $\begin{array}{l}\text { лична права и } \\
\text { обавезе грађанства }\end{array}$ & $\begin{array}{l}\text { уставом } \\
\text { загарантована }\end{array}$ & $\begin{array}{l}\text { ограничење уставних } \\
\text { гаранција }\end{array}$ & уставом загарантована \\
\hline
\end{tabular}

У Табели 1 представили смо својеврстан резиме тематског конструисања парадигми којима су чиниоци вести описивали стање у Србији изазвано општом заразом ковидом-19 у периоду од фебруара до краја маја 2020. године. Из ње се може видети у коликој мери је у вестима конструисана стварност од стране њихових чиниоца. Наиме, једина категорија у потпуности заснована на чињеницама јесте тема личних права и обавеза грађана. О њој се и у вестима у назначеним временским периодима говорило у том смислу - колико оправдано или правно засновано јесте ограничавање Уставом загарантованих права грађана. Све остале теме представљају дискурзивну конструкцију, у мањој или већој мери. Оне које се односе на ковид-19, значи статус заразе, снага болести и њена опасност по појединце јесу биле засноване на одређеним статистичким подацима онда када вирус није више био „смешан“, али су пласиране на такав начин да је тешко било одредити који критеријум опредељује да се о ковиду-19 у Србији говори као о више или мање опасном, заразном, смртоносном и томе слично - број заражених и умрлих, број тестираних, проценат тестираних, проценат заражених и умрлих или нешто друго.

Теме које су се односиле на економију, управљање кризом и државом, односно друштвом у њој, пласиране су од стране чиниоца вести онако како то политичари раде иначе, били у опозицији или на власти - по принципу, „уста моја, хвалите ме“, односно тако да се покаже да су урадили све најбоље што су могли не само да економија не би доживела потпуни суноврат, а друштвене установе пропале, већ и да би економија напредовала, а установе биле оснажене. Сигурно је да постоје стварни параметри на које би се чиниоци вести могли позвати у своју корист у овом случају, али сматрамо да стање представљено таквим изјавама треба посматрати као дискурзивну 
конструкцију, пре свега, из два разлога: 1) у условима ванредног стања и непосредно по његовом окончању било је тешко проверити релевантне податке - а нарочито у компаративној перспективи европских привреда у коју су неки од државних управљача радо сврставали нашу све то време;47 2) још пре увођења ванредног стања знало се да земљу чекају избори, те је очекивано да политичари зборе како зборе и дискурзивно конструишу реалност, што у доброј мери подсећа на антрополошко виђење обредних радњи као оквира за учитавање личних и значења проистеклих из свакодневног друштвеног живота (упор. Laidlaw and Humphrey 1994, 6, 80).

Медијско, односно наративно и дискурзивно успостављање „нове нормалности“" спроведено је на сличан начин, такође. Раније спомињана парадигматска основа нормално-ненормално-(скоро па) нормално успостављена је, најпре, накнадним „проглашавањем“ друштвене свакодневице за „нормалност“ и значењску референтну позицију најважнијих тема које конституишу сваку од засебних парадигми дате основе. Потом је свакодневица временског периода конструисана као наопака, то јест изврнута слика тога - конструисана у вестима након доношења одговарајућих ванредних мера које су је учиниле таквом, у ствари. Напокон, прилично изненадно укидање ванредних мера образложено је конструисањем „нове“ свакодневице, која треба да личи на ону „првобитну“, али и да се истовремено разликује од ње по и даље присутној, мада значајно умањеној здравственој опасности, као и по ефектима мера предузетих у „средњој фази“ читавог временског циклуса од стране државних управљача. Такво констурисање „нове нормалности“ означили смо као медијско због тога што је посредовано медијима у потпуности, као наративно зато што је свака од споменутих тема формулисана као приповест о томе шта је у датом сегменту друштвеног живота било, јесте и биће, а као дискурзивну због успостављања типских, парадигматских јавних говора о сваком од временских периода разматраних овде.

Јасно је да трофазност такве структуре подсећа на обреде прелаза. На први поглед, рекло би се да би констурисање „нове нормалности“ заиста и могло да се означи тако: с једне стране, обреди прелаза јесу они којима се мења статус друштвених субјеката, а са друге стране сама чињеница да три посебне парадигме сачињавају јединствену значењску целину, може да упути на поменуту процесуалност статуса (Bell 1992, 73). Друштвени субјекти су људи, било узети као појединци било као чланови неке групе, и ритуална транзитивност којој су посвећени обреди прелаза односи се на њих. Што се тиче трофазности структуре, која се узима обично као

${ }^{47}$ Председник Србије изјавио је да је сигуран да ће Србија 2020. године бити прва држава у Европи по стопи економског раста. https:/www.b92.net/biz/vesti/ srbija.php?yyyy $=2020 \& m m=05 \& d d=01 \&$ nav_id $=1679935$ 
својство обреда прелаза, за разлику од културно-логички унапред задате и повезане три обредне фазе, оно што разматрамо овде, и како смо то већ изнели, представља накнадно успостављање прве фазе, да би трећа имала смисла, заправо (Leach 1971, 134-136).

Истина је да се може посматрати намера чиниоца вести да конструишу такозвану нову нормалност као друштвену промену на одређени начин, међутим то што се назива новом нормалношћу, односно оно што се наративно и дискурзивно успоставља као различито у односу на уобичајену друштвену свакодневицу - ону пре избијања заразе у Србији, у суштини је исто што и ранија свакодневица, само са извесним бројем преосталих ванредних мера, а чијем укидању се тежи у дискурзивном и практичном смислу. 48 Чак и временско сегментирање друштвених догађаја и стања у друштву на оне „пре короне“ (или пре ванредног стања), затим на оне „за време“ и „после короне“, говори у прилог неоснованости примене модела обреда прелаза у тумачењу здравствене кризе изазване епидемијом ковида-19 у Србији.

Наиме, ковид-19 узет је као критични догађај од стране чиниоца вести, тачније његова појава у Србији и реакција државе на њега искоришћена је као социо-темпорална референтна тачка за медијско пласирање одговора државних званичника на кризу. У том смислу, критични догађај не може се узети, на пример, као фаза сепарације у обредима прелаза, већ као својеврсно стециште дискурса: он је разлог мерама које се предузимају онда када се предузимају и укидају онда када се укидају, он је разлог привременом заустављању друштвеног живота и његовом поновном покретању, он је мерило квалитета стања у држави и сваког појединачног живота и самим тим основа сваког наратива, односно структура сваке теме (Žikić 2012).

\section{Закључак}

Наративно и дискурзивно конструисање стварности кроз вести, посредоване електронским медијима у Србији, посматрано post factum, изгледа у структурном смислу као секуларни обред прелаза којим се друштво уздрмано појавом ковида-19 уводи у такозвану нову нормалност. У таквој конструкцији јасно се могу разликовати временски периоди који одговарају темпоралној сегментацији обреда прелаза која посвећеника најпре издвајају из дотадашње свакодневице, односно социокултурне рутине, затим

48 Бројне мере постепено су укидане, али су поједине остале актуелне или су поново увођене, сходно проценама креатора политика. https:/www.b92.net/info/ vesti/index.php?yyyy $=2020 \& \mathrm{~mm}=05 \& \mathrm{dd}=06 \&$ nav_category $=12 \&$ nav_id $=1681469$ 
га смештају у безстатусну позицију издвојености из ње, да би га потом поново укључили у њу, али овај пут, и након изведених одговарајућих обредних радњи, са промењеним, најчешће узвишеним статусом ${ }^{49}$ (Lič 2001, 117-120). Осим тога што друштва не посматрамо као субјекте обреда прелаза, и наравно тога што не постоје никакве обредне радње којима би се извршио „прелаз“, оно што се назива новом нормалношћу не може се посматрати у таквој перспективи ни зато што представља јединствен догађај у друштвеној повести, док је једно од најзначајнијих својстава обреда - временски контекстуализована опетованост (Leach 1966).

„Нова нормалност“ представља прву реакцију друштвених, то јест државних управљача на друштвену кризу извазвану појавом ковида-19. Дата друштвена криза у Србији огледала се, пре свега, у обустављању већине привредних, као и свих образовних, спортских, културних итд. активности у уобичајенм облику ${ }^{50}$ у периоду од нешто мање од два месеца. Била је праћена увођењем ванредног стања и ограничавањем кретања грађана, а упоредо са свим тим, приоритет је - у стварном и дискурзивном смислу - даван активностима које су имале за циљ да спрече даље ширење заразе у земљи. Онда када је - од стране оне ad hoc формиране структуре, коју смо овде означили као „чиниоци вести“- процењено да рестриктивне мере више нису неопходне, а да је, напротив, неопходно поново покренути општу привредну делатност и друштвени живот у целини, почело је да се говори о потреби повратка у нормалност, али уз стално упозоравање да је та нормалност у извесном смислу условна, односно да зараза није нестала и да се треба понашати „одговорно“.

Постојање друштвене промене које се овим чиниоцима имплицира привременог је карактера, пошто њен дискурзивни и практични циљ представља повратак у „нормалност“, заправо, односно повратак онаквој друштвеној свакодневици каква је постојала пре избијања заразе. Како је то немогуће извршити докле год постоји стварна опасност од поновног разбуктавања заразе ${ }^{51}$, на такво стање потребно је подсећати дискурзивно

49 Изузев ако се не ради о таквим обредним поступцима (пре свега у такозваним световним обредима) које за циљ имају управо супротно - кажњавање, односно унижавање и показивање таквог статуса, као у случајевима телесних и смртних казни, или поступања са посмртним остацима погубљених (Žikić 2018, 383, 385; упор. Vučković 2014).

50 Односно, ко год је то могао, радио је од куће, настава на свим нивоима одвијала се на даљину, а културне установе организовале су своје представе онлајн.

51 О даљем току заразе постоје различита медицинска мишљења и док ово пишемо: једни тврде да је могуће развити имунитет крда, а други не; једни сматрају да вакцине неће бити скоро а да без ње нећемо успети да се изборимо са 
и самим тим, на исти начин, конструисати тренутну слику стварности тако да буде готово као она пре заразе. Посматрана из такве перспективе, „нова нормалност“" није циљ сама по себи, већ - таквим речима неозначено средство ка повратку друштва у његово уобичајено стање, односно у „нормалност“: да бисмо се вратили свакодневици друштвеног живота на коју смо навикли (и коју и сами изнова производимо), неопходно је да прођемо, не кроз фазу привикавања на некакву нову свакодневицу, већ кроз фазу одвикавања - да се тако изразимо - од друштвеног не-живота, до којег је дошло услед појаве ковида-19, али и на накнадну адаптацију на извесне облике социјалног понашања који нас чине „одговорним“, како по сопствено, тако и по здравље других.

Вратимо ли се аналитичкој аналогији констурисања „нове нормалности“ вестима електронских медија, не треба је поредити са фазом агрегације обреда прелаза. Као што смо управо изнели, „нова нормалност“ претходи повратку у првобитно стање друштвене рутине, односно у „нормалност“. Узета као таква, ближа је ономе што се у теорији обреда прелаза назива лиминалношћу: заправо, заједно с оним што је овде означено као „ненормалност“, представља супротност - ако не у формалном, онда свакако у значењском, али и вредносном смислу - „нормалности“. Одатле, значењски, то јест парадигматски однос нормално-ненормално-(скоро па) нормално не представља, дефинитивно, структуру никаквог обреда прелаза, већ указује на културно логичко упориште културној мисли која повезује стање у друштву са дискурзивном концептуализацијом времена, имајући пред собом циљ да објасни све оно што се догађа у друштву.

Пошто је објективно немогуће говорити о томе шта ће се десити у ближој или даљој будућности онда када се то односи на стање целокупног друштва, односно на начин друштвеног живота у целини, а звучати иоле озбиљно - а што је увек циљ оних који управљају друштвом или се барем претварају да тако јесте - користе се културне когнитивне поштапалице да то означимо тако, које истовремено следе уобичајену логику културне комуникације пошиљалац-прималац порука, умирују јавност и показују да они који их користе „знају нешто више“ од осталих грађана, односно да су кадри да управљају ситуацијом. „Нова нормалност“ - одн. дискурзивна производња одговарајуће слике друштвене стварности - представља јед-

корона вирусом, док други не деле то мишљење; неки од њих предвиђају други талас заразе али не могу да се сложе хоће ли бити опасан попут овога, или можда још и гори итд. а у периоду од када смо започели писање (крај маја 2020. године) до када смо га завршили (почетак августа исте године) заиста је дошло до новог јачања заразе, не само у Србији, већ у целом свету, а што је вероватна последица попуштања мера за борбу против заразе уведених на њеном почетку, односно покушаја значајног искорака ка нормализовању друштвеног живота. 
ну такву културну когнитивну поштапалицу, пошто сама по себи не значи ништа, али у контексту свега онога што се са друштвеним животом догодило услед појаве ковида-19, испуњена је културним садржајем који се упола састоји од матрице сличности са ранијом друштвеном рутином, а упола од слике стварности у којој је ту рутину, додуше у једној ограниченој мери, нарушила зараза.

Како се не може рећи оно што сви очекују - а претпостављамо и желе да ће „ствари опет бити онакве какве су биле“, нити се, с друге стране, све ванредне мере донете у циљу заштите од заразе могу у пракси поништити једним потезом, кроз вести се успоставља таква слика стварности која представља припрему за повратак уобичајеној друштвеној рутини. „Нова нормалност“, на тај начин, заједно са „ненормалношћу“ стања у периоду врхунца заразе ковидом-19, треба да представља ознаку привремености којом се потвруђује сталност тока друштвеног времена - само привремено прекинутог заразом, и друштвене свакодневице - такође само привремено измењене заразом. (Свако) друштво хоће да буде јаче од свега што тежи да прекине његову активност и ток времена, те отуд критични догађаји у културном поимању времена и повести и остају референтне тачке - са снажним емотивним набојем, додуше - а не одреднице тог поимања (упор. Žikić 2013, 28-30, 49-50).

\section{Литература}

Alipio, Mark M. 2020. “2019-nCOV scare: 2019nCOV scare: Situation report, role of healthcare professionals and clinical findings." International Journal of Multidisciplinary Health Sciences Research 8 (9): 1-6.

Allen, Lori. 2008. "Getting by the Occupation: How Violence Became Normal during the Second Palestinian Intifada.” Cultural Anthropology 23 (3): 453-487, https:// doi.org/10.1111/j.1548-1360.2008.00015.x

Bell, Catherine. 1992. Ritual Theory, Ritual Practice. New York: Oxford University Press. Bernard-Stoecklin, Sibylle, Rolland P., Silue Y., Mailles A., Campese Ch., Simondon A., Mechain M., Meurice L., Nguyen M., Bassi C., Yamani E., Behillil S., Ismael S., Nguyen D., Malvy D., Lescure F. X., Georges S., Lazarus C., Tabaï A., Stempfelet M., Enouf V., Coignard B., Levy-Bruhl D. Investigation team. 2020. "First cases of coronavirus disease 2019 (COVID-19) in France: surveillance, investigations and control measures, January 2020." Euro Surveill 25(6): pii=2000094. https://doi. org/10.2807/1560-7917. ES.2020.25.6.2000094

Cohen, Anthony P. 1985. The Symbolic Construction of Community. London: Tavistock.

Csordas, Thomas J. 1990. "Embodiment as a paradigm for anthropology." Ethos: Journal of Anthropology 18 (1): 5-47. https://doi.org/10.1525/eth.1990.18.1.02a00010

Csordas, Thomas. 2012. "Embodiment: Agency, Sexual Difference, and Illness." In $A$ companion to the anthropology of the body and embodiment, edited by Frances E. Mascia-Lees, 137-156. Oxford, Mass:Wiley-Blackwell. 
Das, Veena. 1996. Critical Events: An Anthropological Perspective on Contemporary India. Delhi: Oxford University Press.

Gell, Alfred. 1992. The Anthropology of Time: Cultural Constructions of Temporal Maps and Images. Oxford, UK/ Providence, RI: Berg.

Greene, ChristopherJ. Samuel L. Burleson, James C. Crosby, Matthew A. Heimann, David C. Pigott. 2020. "Coronavirus disease 2019: International public health considerations." JACEP Open 2020; 1-8. wileyonlinelibrary.com/journal/emp2, DOI:10.1002/emp2.12040

Howe, Leopold E.A. 1981. "The Social Determination of Knowledge: Maurice Bloch and Balinese Time". Man (n.s.), No 16, 220-234.

Iacobucci, Gareth. 2020. "Covid-19: UK lockdown is "crucial" to saving lives, say doctors and scientists.” BMJ 368:m1204. doi: 10.1136/bmj.m1204

Kam, Kai-Qian, Chee Fu Yung, Lin Cui, Raymond Lin Tzer Pin, Tze Minn Mak, Matthias Maiwald, Jiahui Li, Chia Yin Chong, Karen Nadua, Natalie Woon Hui Tan, Koh Cheng Thoon. 2020. “A Well Infant with Coronavirus Disease 2019 (COVID-19) With High Viral Load.” Clinical Infectious Diseases Feb 28; ciaa201. doi: 10.1093/ $\mathrm{cid} / \mathrm{ciaa} 201$.

Kovačević, Ivan. 2001a. Semiologija mita i rituala I. Tradicija. Beograd: Srpski genealoški centar.

Kovačević, Ivan. 2001b. Semiologija mita i rituala II. Savremeno društvo. Beograd: Srpski genealoški centar.

Laidlaw, James, Caroline Humphrey. 1994. The Archetypal Actions of Ritual: A Theory of Ritual Illustrated by the Jain Rite of Worship. Oxford, UK: Oxford University Press

Leach, Edmund. 1966. "Ritualization in Man in Relation to Conceptual and Social Development". Philosophical Transactions of the Royal Society of London. Series B, Biological Sciences 251 (772): 403-408. doi: 10.1098/rstb.1966.0026

Leach, Edmund. 1971. Rethinking Anthropology. London/ New York: The Athlone Press/ University of London Press/ Humanities Press Inc.

Leach, Edmund. 1982. Social Anthropology. Glasgow: Fontana.

Lič, Edmund. 2001. Kultura i komunikacija. Logika povezivanja simbola. Uvod u primenu strukturalističke analize u socijalnoj antropologiji. Beograd: XX vek.

Lichfield, Gideon. 2020. "We're not going back to normal." MIT Technology Review, March 17, https:/www.technologyreview.com/2020/03/17/905264/coronavirus-pandemic-social-distancing-18-months/

Milosavljević, Ljubica. 2010a. "Konstrukcija starosti: štampa o domovima za stare (1945-1960)." Etnoantropološki problemi 5 (2): 165 - 183. https://doi.org/10.21301/ eap.v5i2.8

Milosavljević, Ljubica. 2010b “"Namćori” iz komšiluka: predstavljanje starosti u domaćoj televizijskoj reklami." Etnoantropološki problemi 5 (3): 75 - 97. https://doi. org/10.21301/eap.v5i3.4

Milosavljević, Ljubica. 2018. "Sarost kao resurs na primeru socijalnog rada." Antropologija 18 (1): 59-71.

Mur, Sali F, Barbara G. Majerhof. 1984. "Sekularni ritual: forme . značenja. " Glasnik Etnografskog instituta SANU XXXIII:117-139. 
Pišev, Marko, Bojan Žikić, Mladen Stajić. 2020. „Indeks „korona“: simbolička upotreba kovida-19 u javnom govoru Srbije“. Etnoantropološki problemi 15 (3): 795-827. doi Singer, Merrill. 2004. "The social origins and expressions of illness." British Medical Bulletin 69, 9-19, https://doi.org/10.1093/bmb/ldh016

Takeuchi, Ichiro. 2020. "COVID-19 first stage in Japan - how we treat 'Diamond Princess Cruise Ship' with 3700 passengers?” Acute Medicine \& Surgery 7: e506. doi: 10.1002/ams 2.506

Turner. Victor. 1969. The Ritual Process. Structure and Anti-Structure. Ithaca, NY: Cornell university Press.

van Gennep, Arnold. 1969. The Rites of Passage. Chicago, Il: University of Chicago Press.

Vučković, Marija. 2014. "Koncept 'loše smrti'“. " Etnoantropološki problemi 9 (2): 513-537. https://doi.org/10.21301/eap.v9i2.12

Xu, Xiao-Wei, Xiao-Xin Wu, Xian-Gao Jiang, Kai-Jin Xu, Ling-Jun Ying, Chun-Lian Ma, Shi-Bo Li, Hua-Ying Wang, Sheng Zhang, Hai-Nv Gao, Ji-Fang Sheng, HongLiu Cai, Yun-Qing Qiu, Lan-Juan Li. 2020. "Clinical findings in a group of patients infected with the 2019 novel coronavirus (SARS-Cov-2) outside of Wuhan, China: retrospective case series." BMJ 368:m606 http://dx.doi.org/10.1136/bmj.m606

Zarocostas, John. 2020. "How to fight an infodemic." Lancet 395 (10225): 676. https:// doi.org/10.1016/S0140-6736(20)30461-X

Žikić, Bojan. 2006. Antropologija AIDS-a. Rizično ponašanje intravenskih korisnika droge. Beograd: Filozofski fakultet i Srpski genealoški centar.

Žikić, Bojan. 2011. "Koliko je "srpski” Srpski film? Konceptualizacija kulturno normalnog i nenormalnog u savremenoj Srbiji”. Etnoantropološki problemi 6 (2): 381-412. https://doi.org/10.21301/eap.v7i4.1

Žikić, Bojan. 2012. "Vremenska kontekstualizacija kulturnih predstava o postsocijalizmu, tranziciji i evrointegracijama u Srbiji.” Etnoantropološki problemi 7 (4): 783 805. https://doi.org/10.21301/eap.v6i2.6

Žikić, Bojan. 2013. Slike u izlogu: kulturne predstave o Evropskoj uniji kao sredstvo opisivanja paralelne stvarnosti stanju u Srbiji 1991-2011. Beograd: Odeljenje za etnologiju i antropologiju Filozofskog fakulteta i Srpski genealoški centar.

Žikić, Bojan. 2018. Antropologija tela. Beograd: Odeljenje za etnologiju i antropologiju Filozofskog fakulteta i Dosije studio. 
Bojan Žikić

Department of Ethnology and Anthropology, Faculty of Philosophy, University of Belgrade, Serbia

Mladen Stajić Institute of Ethnology and Anthropology, Faculty of Philosophy, University of Belgrade, Serbia

Marko Pišev

Institute of Ethnology and Anthropology, Faculty of Philosophy, University of Belgrade, Serbia

The New Normal and Covid-19 in Serbia from February to May 2020.

The situation caused by the appearance of Covid-19 can be viewed as a critical event: typologically, it is an unprecedented event, which requires and shapes new forms of historical action hitherto unknown in the given context. Critical events serve as strong value and emotional landmarks in the cultural cognition of each social environment, and form the basis for a meaningful determination towards other events. Using material collected primarily from the online versions of electronic and printed media, we consider how the reality they presented is shaped through the news through the statements of politicians and medical doctors in Serbia. We trace how the narrative transformation of socio-cultural reality took place from the time before the of Covid-19 outbreak in our country to the time immediately after the lifting of the state of emergency declared due to that infection. The premise of all that is being done to tackle the infection is not a purpose in itself, but aims to enable a return to the life we were accustomed to before the outbreak of the epidemic. Covid-19 destabilizes our everyday life - a life that consists of work or study, use of free time, socializing etc. Such everyday life is a reference point of "normalcy". Socio-cultural normalcy refers to all that is understood as a normal and undisturbed course of everyday life. The appearance of Covid-19 gave rise to the notion of the "new normal", that is, a course of everyday life that is similar to normal, ordinary life, but with adherence to measures aimed at preventing the spread of infection by the authorities. In the paper we deal with the period that begins just before the outbreak of Covid-19 in our country, and ends with the period after the lifting of the state of emergency, to show the discursively produced picture of social reality in which the concept of the "new normal" serves as a cultural cognitive tool for understanding a situation in which one has to live with Covid-19 in order to one day be able to return to the way of life that existed before it.

Key words: social and cultural normalcy, critical event, rites of passage, cultural cognition, electronic / internet media 
Nouvelle normalité sociale et culturelle et covid-19 en Serbie de février jusqu'en mai 2020

L'état provoqué par l'apparition du covid-19 peut être considéré comme un événement critique: d'un point de vue typologique, il s'agit d'un événement sans précédent, qui exige et façonne de nouvelles sortes d'activité historique, jusqu'à aujourd'hui inconnue dans le contexte donné. Les événements critiques servent de repères axiologiques et émotifs dans la cognition culturelle de chaque milieu et c'est à partir d'eux que se positionnent d'autres événements. En prenant pour appui le matériel recueilli principalement dans les médias électroniques et les médias imprimés dans leur version numérique, nous analysons à partir de ces informations de quelle manière est façonnée la réalité dans les déclarations des décideurs de l'État et des médecins en Serbie. Nous montrons comment s'est déroulée la métamorphose narrative depuis la réalité socioculturelle du temps avant l'apparition de la contagion générale par le covid-19 dans notre pays jusqu'à la période qui a immédiatement suivi la sortie de l'état d'urgence proclamé en raison de cette contagion. L'hypothèse est que tout ce que l'on fait et ce qui a été fait pour surmonter la contagion n'est pas un objectif en soi, mais que l'objectif en est de permettre le retour à la vie à laquelle on était habitué avant l'apparition de la contagion. Par le covid-19 c'est notre quotidien qui est déstabilisé - une vie faite de travail ou d'études, de temps libre, de fréquentation des amis etc. Un tel quotidien est le point référentiel de la „normalité". La normalité socioculturelle équivaut au déroulement habituel et paisible de la vie quotidienne, c'est-à-dire de nos activités. L'apparition du covid-19 a fait naître la notion de la ,nouvelle normalité“, c'est-à-dire d'un tel déroulement de la vie quotidienne qui ressemble à la vie normale, habituelle, mais qui est accompagnée d'une série de mesures adoptées par les autorités dont l'objectif est d'empêcher la propagation de la contagion. Dans ce texte nous traitons la période commençant juste avant l'apparition de la contagion du covid-19 dans notre pays et se terminant par la sortie de l'état d'urgence, pour montrer comment se produit discursivement l'image de la réalité sociale dans laquelle la notion de la „nouvelle normalité" a un rôle médiateur culturel et cognitif explicatif de la situation dans laquelle il faut vivre avec la contagion pour pouvoir un jour retourner à la façon de vivre telle qu'elle a existé avant.

Mots clés: normalité sociale et culturelle, événement critique, rites de passage, cognitivité culturelle, médias électroniques/internet

Primljeno / Received: 14.08.2020.

Prihvaćeno / Accepted: 2.09.2020. 